\title{
Influence of Independence, Due Professional Care and Accountability on Audit Quality on the Audit Board of The Republic of Indonesia Representative Province of South Sumatra
}

\author{
Fipiariny. $\mathrm{S}^{1, *}$ Nurhayati Nurhayati ${ }^{1}$ \\ ${ }^{1}$ Accounting Study Program, Anika Palembang Polytechnic \\ "Corresponding author. Email: vie.ariny@gmail.com
}

\begin{abstract}
The goal of this study is to determine the impact of independence, appropriate professional care, and accountability on audit quality at the CPC of the Republic of Indonesia Representative of South Sumatra Province. A questionnaire given to BPK auditors was used to collect data for this investigation. Many of the 40 questionnaires provided are filled and comprehensive, and can be used as research data. The study's findings include BPK auditors' independence and Due Professional Care. Auditors from BPK have a good and considerable impact on audit quality, whereas accountability has no impact on audit quality. Simultaneous hypothesis testing reveal that BPK auditor independence, Due Professional Care, and auditor accountability are all important factors in the audit's quality.
\end{abstract}

Keywords: Independence, due professional care, accountability and audit quality.

\section{INTRODUCTION}

The purpose of financial statements is to offer financial information about a company. These financial statements will be used to analyze the organization's financial management's accountability and transparency, as well as to assist users in making decisions. Financial statements should be audited to strengthen the user's confidence in the information presented. According to Agoes [1], an audit is a critical and systematic study of financial statements generated by management, as well as bookkeeping records and supporting data, by independent parties with the goal of providing a judgement on the financial statements' fairness.

According to Law No. 15 of 2004, external auditors, in this case the Audit Board, perform audit services on financial statements in the government, both national and municipal governments (BPK). This audit is a method of identifying problems, analyzing them, and evaluating them independently, objectively, and professionally using examination criteria to determine the truth, correctness, credibility, and dependability of information about the country's management and financial responsibilities. Article 23E of the 1945 Constitution, Law No. 15 of 2004 on Examination of State Financial Management and Responsibility, and Law No. 15 of 2006 concerning the Audit Board all require BPK to conduct audits.

BPK conducts audits of government financial statements in accordance with the Explanation of Article 16 paragraph (1) of Law No. 15 of 2004 to provide an opinion on the fairness of financial information provided in government financial accounts. Compliance with government accounting standards, proper disclosures, compliance with laws and regulations, and the efficacy of internal control systems are all criteria used to determine the fairness of this financial data. After completing the audit process, BPK issues an opinion on the accuracy of financial data.

The development of BPK audits of regional financial statements in South Sumatra continues to improve, with only one local government receiving a Fair Opinion With Exception (WDP) in 2018, namely Penukal Abab Lematang Ilir Regency, which is one of the New 
Regencies, while all local governments receive a Reasonable Without Exception (WTP) opinion in 2019 (BPK Representative of South Sumatra Province, 2021).

The role of bpk utma is not only to provide an opinion on the region's financial accounts, but also to determine how the audit quality may be maintained and improved. Independence is one feature that can help to improve audit quality. According to Arens et al. [2, audit independence entails a neutral mental attitude when gathering and analyzing evidence. As a result of his or her efforts, the auditor must be able to maintain and improve the audit's quality. "In all aspects relevant to involvement, the auditor must retain independence in mental attitudes," according to the second general standard in Minarni [3] (SA section 220 in SPAP, 001).

The phenomenon that occurred to the auditor of the financial examination agency (BPK) in 2009 got a case that befell BPK auditor Bagindo Quirino as a suspect. Bagindo Quirino is indicated to have received a bribe from former Depnakertrans official Bahrun Effendi amounting to $\operatorname{Rp} 650,000,000$, the money was given to change the findings made by bpk auditor (http://nasional.kompas.com). There is also a bribery case in 2011, bpk republic of Indonesia North Sulawesi by mayor Tomohon is unethical that makes bpk ri auditors doubt its independence. This case originated from the Financial Report of the Tomohon City Government. Bpk auditors allegedly received $\mathrm{Rp}$ $600,000,000$ from Mayor Tomohon. The provision of this bribe money so that tomohon's financial report is declared reasonable status with exceptions.

BPK auditors allegedly received Rp 600,000,000 from Mayor Tomohon. The provision of this bribe money so that tomohon's financial report is declared reasonable status with exceptions. BPK auditors also get facilities in the form of hotels and vehicle rentals from tomohon city government funds amounting to Rp.7,500,000. One of the factors that can maintain the quality of audits as above is accountability.

Accountability is a psychological motivation that motivates a person to work hard and take responsibility for all acts and decisions he takes in his environment. The environment refers to the setting or location in which a person conducts his or her activities or works, which can have an impact on the conditions around him.

Furthermore, one of the main things that auditors must be able to effect the quality of audits is Due Professional Care. According to Badjuri [4,] due professional care or meticulous and careful professional skills are an important self-condition to be used in audit activity. Similarly, the second basic criterion stipulates that "the auditor shall apply his professional expertise carefully and attentively in the performance of the audit and the writing of the audit report."
Linting (2013), Nugraha (2015), Chairunnisa, K. did previous research on the quality of audits performed by BPK auditors (2016). as well as Sugiarmini and Luh (2017) [5][6][7][8], although they did not include accountability variables in their study, whereas Zoja [9] did include accountability variables but not Due Professional Care measures.

\subsection{Research Issues}

Researchers are interested in conducting research on the impact of independence, due professional care, and accountability on audit quality in BPK Republic of Indonesia Representative of South Sumatra Province based on the foregoing background.

\section{REVIEW OF THE LITERATURE}

\subsection{Research Issues}

Freiz Heider (1896-1988) was an Austrian psychologist who developed the Attribution Theory, according to Chyntya (2018) [10]. The idea of attribution describes how people explain (make attributions about) other people's and their own conduct. The attribution process is the process of assessing whether an observed behavior or event is primarily caused by an internal or external component [11]. Characteristics (such as personality, motivation, and attitude) can be attributed to behavior, or events can be assigned to behavior (such as external pressures, social norms, peer pressures, natural disasters and so on).

\subsection{Audit Quality}

The quality of the audit is critical, and auditors must maintain it throughout the auditing process. Audit quality, according to De Angelo (2012), is the likelihood that an auditor will uncover and disclose irregularities on a client's accounting system. The goal of the audit quality is to persuade the client and the general public of the profession, which includes the auditor's professional quality. When an auditor follows established professional standards, the audit is of high quality.

\subsection{Auditor Independence}

Based on SPAP (2016) related to the independence of each KAP must establish policies and procedures designed to provide adequate confidence that KAP and its personnel, and where relevant, to other parties who are also required to comply with the provisions of independence (including KAP Network personnel), to maintain their independence in accordance with the applicable professional ethics provisions. BPK members In carrying out their duties and authorities, examiners must follow ethical concepts such as independence, 
honesty, and professionalism, which are the BPK's core values.

\subsection{Due Professional Care Auditor}

Due professional care entails exercising professional skill with care and precision. "Examiners must employ professional skill, professional skepticism, and professional consideration throughout the examination process," according to the Regulation of the Audit Board of the Republic of Indonesia's statement of examination requirements. Professional skepticism is required by the auditor's thorough and careful application of professional abilities. Professional skepticism is a mindset that constantly asks questions and assesses audit evidence critically. Auditors can establish adequate confidence that financial statements are free of serious misstatements, whether produced by error or fraud, if they apply their professional expertise carefully and carefully."

\subsection{Auditor Accountability}

The word "accountability" comes from the English word "accountability," which meaning "accountability" or "circumstances to be held accountable for." "Accountability is a sort of psychological drive that makes a person try to resolve and account for all actions and decisions taken and convey to his environment or to those who have rights," Tetclock writes in Tandirerung [12]. The auditor who has an awareness in himself about his role for society and for his profession then he will have the confidence, motivation and effort to do the work to the maximum, so that he can make a great contribution to society and his profession.

Some indicators that can be used to measure a person's accountability are a person's motivation to get the job done, how much effort and thinking is devoted to completing the job, and finally the belief that his work will be examined by his superior. It is concerned with internal or external factors that exist in an individual's behaviour.

\subsection{Hypothesis}

The hypotheses in this study are:

H1: The auditor's independence has a favorable impact on the audit's quality..

$\mathrm{H} 2$ : Auditors who exercise due professional care have a favorable impact on audit quality.

H3: Accountability of auditors has a beneficial impact on audit quality.

H4: The quality of audits is influenced concurrently by independence, proper professional care, and auditor accountability.

\section{RESEARCH METHODS}

\subsection{Population and Sample}

The BPK auditor representative of South Sumatra Province was the population studied in this study. And the sample is made up of $40 \mathrm{BPK}$ auditors who have worked for more than two years as BPK auditors, chosen at random.

\subsection{Operational Definition and Variable Measurement Audit Qualit}

Any potential that the auditor, when inspecting the client's financial accounts, will find violations in the client's accounting system and record them in the audit report is referred to as a quality audit. The audit's quality was assessed in this study:

1. Conformity of Examination with Audit Standards.

2. Quality of Examination Results

\subsection{Auditor Independence}

In carrying out their duties and authorities, CPC members and examiners must follow ethical concepts such as independence, integrity, and professionalism, which are the CPC's core values. The independence of auditors was assessed in this study:

1. Independence of program preparation

2. Independence of the implementation of the work

3. Independence of reporting

\subsection{Due Professional Care Auditor}

Due professional care means professional proficiency carefully and carefully. In this study Due Professional Care Auditor Due professional Care measured by:

1. Throughout the examination process, the examiner should employ professional proficiency, professional skepticism, and professional deliberation with care and precision.

2. Use of professional skills carefully and thoroughly. 


\subsection{Auditor Accountability}

Accountability refers to situations that must be accounted for or for which someone must be held responsible.

In this study Auditor Accountability was measured by:

1. One's motivation to get the job done,

2. How much effort and effort is devoted to completing the work

3. Confidence that his work will be examined by his superiors

\subsection{Types of Data and Technical Analysis}

Primary data collected through questionnaires was used. The quantitative descriptive analysis technique was utilized to process questionnaire data that was titrated using the likert scale.

\subsection{Data Testing}

The data tests carried out in this study are as follows:

\subsubsection{Data Quality Test}

Data quality tests in this study are conducted through validity tests and rehabilitation tests to determine the accuracy and consistency of the data collected

\subsubsection{Classic Assumption Test}

To guarantee that the data is normal and viable, or BLUE, in this test. Typical assumption tests include the following:

1) Normalistas Test

2) Multicollinearity Test

3) Autocoleration Test

\subsubsection{Descriptive Statistics}

Descriptive statistics are numbers that are used to describe information that has been gathered.

\subsubsection{Multiple Regression Test}

Multiple regression analysis, dubbed linear since each estimate of the value is predicted to increase or decrease in a straight line, was used to measure variable effect incorporating more than one free variable (X1, $\mathrm{X} 2, \mathrm{X} 3$ ).

\subsubsection{Determination Coefficient Test $\left(R^{2}\right)$}

The coefficient of determination (R2) effectively assesses the model's capacity to explain variations in dependent variables, according to (Ghozali, 2012 in Marlisa, 2016). Between zero and one is the coefficient of determination. The ability of independent variables to explain the fluctuation of dependent variables is severely constrained when the R2 value is low.

\subsubsection{Hypothesis Test}

The $t$ (partial) statistical test is used to see how each free variable affects the constrained variable independently. The statistical test F determines whether all of the model's dependent variables have a combined effect on independent variables.

\section{RESULTS OF RESEARCH AND DISCUSSION}

\subsection{Research Results}

\subsubsection{Description of Research Sample}

The purpose of this study is to collect data from auditor research objects of the Audit Board of the Republic of Indonesia Representative of South Sumatra Province utilizing questionnaires. Because they are now in BPK implementing Work From Home (WFH) and carrying out activities, not all of the questionnaires distributed are filled out by respondents. The survey was completed but incomplete, and there were no favorable comments from respondents. There are 32 questionnaires filled out and used as study samples out of the 40 that were delivered, as shown in table 1:

Table 1. Questionnaire Distribution

\begin{tabular}{|l|c|c|}
\hline \multicolumn{1}{|c|}{ Description } & $\begin{array}{l}\text { Questionnaire } \\
\text { Number }\end{array}$ & Percentage \\
\hline $\begin{array}{l}\text { Questionnaires are } \\
\text { disseminated. }\end{array}$ & 40 copies & $100 \%$ \\
\hline $\begin{array}{l}\text { The returned } \\
\text { questioner }\end{array}$ & 82 copies & $80 \%$ \\
\hline $\begin{array}{l}\text { Questionnaires that } \\
\text { are not fully } \\
\text { reviewed/ returned. }\end{array}$ & $20 \%$ \\
\hline $\begin{array}{l}\text { Total questionnaires } \\
\text { that can be processed. }\end{array}$ & 32 copies & $80 \%$ \\
\hline respondent rate $=\underline{32} \times 100 \%=80 \%$ \\
\hline \multicolumn{1}{|c|}{40} \\
\hline
\end{tabular}

Source: Data processed 2021

After determining the data's quality, and the classical assumptions are obtained the data results are worth processing. 


\subsubsection{Multiple Linear Regression Analysis}

Hypothesis testing using multiple regressions appears in table 2 below:

Table 2. Multiple Regression Analystia Results Coefficients $^{\mathrm{a}}$

\begin{tabular}{|l|r|r|r|r|r|}
\hline Model & \multicolumn{2}{|c|}{$\begin{array}{c}\text { Unstandardized } \\
\text { Coefficients }\end{array}$} & $\begin{array}{r}\text { Standardi } \\
\text { zed } \\
\text { Coefficie } \\
\text { nts }\end{array}$ & $\mathrm{t}$ & Sig. \\
\cline { 2 - 4 } & \multicolumn{1}{|c|}{ B } & \multicolumn{1}{|c|}{$\begin{array}{c}\text { Std. } \\
\text { Error }\end{array}$} & Beta & & \\
\hline $\begin{array}{l}\text { (Constan } \\
\text { t) }\end{array}$ & 42,131 & 6,808 & & 6,188 &, 000 \\
$\begin{array}{l}\text { Independ } \\
\text { ensi }\end{array}$ &, 252 &, 118 &, 360 & 2,135 &, 042 \\
$\begin{array}{l}\text { DueProf } \\
\text { Care }\end{array}$ &, 413 &, 176 &, 560 & 2,345 &, 026 \\
$\begin{array}{l}\text { Akuntabi } \\
\text { litas }\end{array}$ &, 224 &, 190 &, 282 & 1,180 &, 048 \\
\hline
\end{tabular}

a. Dependent Variable: Audit

Source: Data processed 2021

The regression equation of this Multiple Regression Analysisia result is:

$$
\mathrm{Y}=42,131+0,252 \mathrm{X} 1+0,413 \mathrm{X} 2+0,224 \mathrm{X} 3+\mathrm{e}
$$

\subsubsection{Determination Coefficient Test $\left(R^{2}\right)$}

Determination Coefficient Test (R2) appears in table 2 below:

Table 3. Determination Coefficient Test Results Model Summary

\begin{tabular}{|l|r|r|r|r|}
\hline $\begin{array}{l}\text { Mod } \\
\text { el }\end{array}$ & $\mathrm{R}$ & $\begin{array}{c}\mathrm{R} \\
\text { Square }\end{array}$ & $\begin{array}{c}\text { Adjusted R } \\
\text { Square }\end{array}$ & $\begin{array}{c}\text { Std. Error } \\
\text { of the } \\
\text { Estimate }\end{array}$ \\
\hline 1 &, $495^{\mathrm{a}}$ &, 245 &, 164 & 2,91931 \\
\hline
\end{tabular}

a. Predictors: (Constant), Akuntabilitas, ndependensi,

DueProfCare

b. Dependent Variable: Audit

When viewed from table 13 above the value of $\mathrm{R}$ Square (determination koefisen) is 0.245 or $24.5 \%$ showing the variable Independence, Due Professional Care, Accountability can explain the Audit Quality variable. The remaining $75.5 \%$ was explained by factors not found in the study.

\subsubsection{Hypothesis Test}

In this study, the F test attempts to co-author the influence of Independence, Due Professional Care, and Accountability on Audit Quality factors. The value used in this $\mathrm{F}$ test is the value of $\mathrm{F}$ and its significant value from the anova table shown in the table below. This test compares the significant value of $F$ value, which is less than 0.05 , with the value $\mathrm{F}$ count provided in the anova table.

Table 4 Test Results F (Simultaneous) ANOVA ${ }^{\mathrm{a}}$

\begin{tabular}{|c|c|c|c|c|c|}
\hline Model & $\begin{array}{l}\text { Sum of } \\
\text { Squares }\end{array}$ & $\mathrm{df}$ & $\begin{array}{l}\text { Mean } \\
\text { Square }\end{array}$ & $\mathrm{F}$ & Sig. \\
\hline $\begin{array}{l}\text { Regressi } \\
\text { on }\end{array}$ & 77,373 & 3 & 25,791 & 3,026 &, $046^{\mathrm{b}}$ \\
\hline Residual & 238,627 & 28 & 8,522 & & \\
\hline Total & 316,000 & 31 & & & \\
\hline
\end{tabular}

The significance of the value $f$ of 0.046 below 0.05 , as shown in table 4 , indicates that the variables of independence, due professional care, and accountability have a substantial impact on the Audit Quality variable.

\subsubsection{Test t (Partial)}

The $\mathrm{t}$ test determines if an independent variable has a partial effect on a dependent variable. The following table shows the findings of the test on the effect of independence variables, due professional care variables, and accountability to audit quality variables.:

Table 5. Test Results t (Partial) Coefficients ${ }^{\mathrm{a}}$

\begin{tabular}{|c|c|c|c|c|c|}
\hline \multirow[t]{2}{*}{ Model } & \multicolumn{2}{|c|}{$\begin{array}{l}\text { Unstandardize } \\
\text { d Coefficients }\end{array}$} & \multirow{2}{*}{\begin{tabular}{|c|}
$\begin{array}{c}\text { Standar } \\
\text { dized } \\
\text { Coeffici } \\
\text { ents }\end{array}$ \\
Beta
\end{tabular}} & \multirow[t]{2}{*}{$\mathrm{t}$} & \multirow[t]{2}{*}{ Sig. } \\
\hline & B & $\begin{array}{l}\text { Std. } \\
\text { Error }\end{array}$ & & & \\
\hline (Constant) & 42,131 & 6,808 & & 6,188 & ,000 \\
\hline Independensi &, 252 & ,118 & 360 & 2,135 &, 042 \\
\hline DueProfCare & ,413 & , 176 &, 560 & 2,345 & 026 \\
\hline Akuntabilitas & ,224 & 190 & ,282 & 1,180 & 048 \\
\hline
\end{tabular}

a. Dependent Variable: Audit

Source: Data processed 2021 
The value $t$ of each variable can be determined using table 5:

\section{The Effects of Independent Variables}

The significance level value of the $t$ test for the Independence variable of 0.042 is smaller than $=0.05$ and the regression coefficient value of 0.252 is based on the table above. These findings suggest that independence has a considerable and favorable impact on audit quality.

\section{The Importance of Professional Care}

The significance level value of the $t$ test for the Due Professional Care variable of 0.026 is smaller than $=$ 0.05 , and the regression coefficient value of 0.413 are based on the table above. Due Professional Care has a favorable and considerable impact on audit quality, according to these findings.

\section{Influence of Accountability}

The significance level value of the $t$ test for the Accountability variable was 0.048 smaller than $=0.05$, and the regression coefficient value was 0.224 , based on the table above. These findings suggest that audit quality is influenced by accountability.

\subsection{Discussion}

\subsection{1.. The independence of the auditor has a positive effect on the quality of the audit}

Based on the results of the significance level of the test $\mathrm{t}$ for the Independence variable of 0.042 smaller than $=0.05$ and the regression coefficient value of 0.252, the independence of the BPK Auditor representative of South Sumatra Province had a positive and significant effect on the audit quality. This indicates that the $\mathrm{H} 1$ theory is valid.

The findings of this study show that the greater the auditor's independence in the BPK Representative of South Sumatra Province, the more skinned the audit outcomes become. In relation to any examination task, the organization of examiners and examiners shall be free of personal, external, and organizational problems that may impair their independence in their mental attitudes and appearance. The organization of examiners and their examiners are responsible for maintaining their independence in such a way that the opinions, simultaneous results, considerations, or suggestions of the examination results are not impartial to any party, both in appearance and reality. As a result, the process of verification and identification between auditors and audits has been carried out in each audit assignment in order to maintain independence.

The findings of this study back up Puspatriani's (2016) research, which found that audit quality is significantly affected by independence.

\subsection{2.. Due Professional Care auditors have a positive effect on the quality of audits}

Due Professional Care Auditor BPK Representative Based on the findings of the test significance level value $\mathrm{t}$ for the Independence variable of 0.026 smaller than $=$ 0.05 and regression coefficient value of 0.413 , due Professional Care Auditor BPK Representative of South Sumatra Province positively and significantly on the quality of the audit. This confirms that the $\mathrm{H} 2$ theory is valid.

According to the findings of this study, a better Due Professional Care uditor at BPK Perwakilan, South Sumatra Province, will be able to detect fraud with more critical and severe audit outcomes. The quality of audits is significantly reliant on an auditor's due professional care. If an auditor has good due professional care, the quality of audits is greatly improved.

Due professional care is maintained by continuing auditor education and training so that auditors' skin is maintained as science, technology, and financial statement making systems evolve, as well as applicable regulatory changes, so that auditors can follow and understand the objects audited and detect errors, fraud, and audit non-compliance with applicable regulations. Furthermore, BPK already has its own Training Hall.

The findings of this study support Puspatriani's [13] research, which claims that due professional care has an impact on audit quality.

\subsection{3.. Auditor accountability has a positive effect on the quality of audits.}

Based on the results of the test significant level value $t$ for Independence variable of 0.048 smaller than $=0.05$ and regression coefficient value of 0.224 , BPK Auditor Accountability Representative of South Sumatra Province positively influences the quality of this audit. This confirms that the $\mathrm{H} 3$ hypothesis is valid.

The findings of this study show that the more accountable auditors in bpk representatives of South Sumatra province are, the more skinned the audit outcomes are. Every assignment and piece of labor that the auditor completes must be held to a high standard of accountability. Audit outcomes are held accountable not just by the audit team, but also by a multi-tiered review process that includes more than simply the conclusions of the lead audit team.

The findings of this study back the research by Purnamasari, et al. [14], who found that audit quality is influenced by accountability. 


\subsection{4.. Independence, Due Professional Care and auditor accountability have simultaneous influence on audit quality}

Simultaneous test findings demonstrate that the value $\mathrm{f}$ of 0.046 has a significance of less than 0.05 , implying that the variables of independence, due professional care, and accountability have a substantial impact on the Audit Quality variable. This confirms that the $\mathrm{H} 4$ hypothesis is valid.

Auditors at BPK Representative of South Sumatra Province have applied Independence, Due Professional Care, and Accountability to improve the quality of audits, according to the study's findings. The quality of the audit is strongly based on an auditor's due professional care; if an auditor has good due professional care, the audit will undoubtedly be good; also, an auditor must be neutral and independent, not siding with anyone and in every assignment. In addition, effective accountability will improve the audit's quality.

\section{CONCLUSIONS, LIMITATIONS AND SUGGESTIONS}

\subsection{Conclusion}

The following conclusions can be drawn from talks held at the Audit Board of the Republic of Indonesia Representative of South Sumatra Province about the impact of independence, proper professional care, and accountability on the quality of audits:

1. BPK Auditor Independence, Professional Care, and Accountability Based on the results of the value of the significance level of the test $t$ for the independence variable of 0.042 , for the Variable Due Professional Care of 0.026, and for the Accountability variable of 0.048 smaller than $=$ 0.05 , bpk auditor representative of South Sumatra province partially positively and significantly on the quality of the audit. The quality of audits is influenced concurrently by independence, due professional care, and auditor accountability. When the significance of the value $f$ of 0.046 is less than 0.05 and the results of simultaneous tests demonstrate that, it can be argued that.

2. The quality of audits is influenced concurrently by independence, due professional care, and auditor accountability. Simultaneous test findings demonstrate that the value $\mathrm{f}$ of 0.046 has a significance of less than 0.05 , implying that the variables of independence, due professional care, and accountability have a substantial impact on audit quality factors.

3. According to the results of the determination test, the free variables and dependent variables utilized in this study can only explain 24.5 percent of the bound variable; the remainder can be explained by factors outside the model.

\subsection{Limitations}

The study's weakness is that out of the 40 questionnaires provided, only 32 auditor respondents filled out surveys. Only 24.5 percent of the bound variables can be described by the free variables and dependent variables employed in this study; the remainder can be explained by variables outside the model. As a result, more research is needed to be able to employ other more relevant variables as measurements of audit quality, such as competence, auditor ethics, and integrity, especially in bpk representative of South Sumatra region.

\subsection{Suggestion}

Based on the findings of the research, the bpk representative for the province of South Sumatra can be advised on how to maintain and improve the quality of audits by remaining independent, improving the quality of auditors through education and training, and always maintaining accountability and integrity.

\section{REFERENCES}

[1] Agoes, Sukrisno. 2012 Auditing Volume I \& II (Accounting Examination) by Public Accounting Firm of the Faculty of Economics, University of Indonesia, Jakarta: Salemba Empat

[2] Arens, A. A., Elder, J.R., Beasley, M. S., and Jusuf. 2012. Auditing and Assurance Services: Integrated Approach (Indonesian Adaptation). Jakarta: Salemba Four.

[3] Minarni A.Dethan.2016. Competence and Independence in Audit Quality. Auditor: A theoretical approach. Dethan/ Journal Of Management (Sme's) Vol. 2, No.1, 2016, P77-93.

[4] Badjuri, Achmad. 2011. Factors That Affect the Quality of Independent Auditor Audits (Study at Public Accounting Firms in Central Java). Journal of Financial Accounting and Banking (Volume 3, Number 2

[5] Linting, Indriyanti. 2013. Influence of Competence, Objectivity, Independence and Performance of Internal Auditors on Audit Quality at BPK RI Inspectorate of Makassar. Faculty of Economics and Business Hasanuddin University.

[6] Nugraha A.2015. Influence of Experience, Due Professional Care and Independence of Auditors on Audit Quality on Auditor Inspectorate and BPK RI Representative of West Java Province. Bandung: Computer University of Indonesia 
[7] Chairunnisa, K. (2016). Aanlysis Factors that affect the Quality of The Results of the Examination of State Finance empirical studies in BPK RI Representative of East Java Province. Journal of accounting faculty of economics. Vol. 10. No.3. ISSN 2701-4119

[8] Sugiarmini, N.L.A. and Luh. K.D. (2017), Influence of professional skepticism, independence, Competence, Ethics, and Role stress auditors on the quality of audits at the BPK RI Office representative of Bali Province. Krisna Journal. Vol. 9. No. 1. ISSN: 2301-8879

[9] Zoja, I Putu Hatesa Twenta. 2014. Influence of Independence, Experience, Accountability, Integrity, and Professionalism on Audit Quality at bpk ri financial examiner agency in Central Java and Yogyakarta. Faculty of Economics and Business, Diponegoro University, Semarang

[10] Chyntya Suci C. and Made Dudy Satyawan.2018. Effect of The Application of Principles - Principles of State Financial Examination on the Quality of Audits of the Publik.ejournal.unesa.ac.id Sector

[11] McShane, Steven L. \& Von Glinow, Mary Ann. (2008)." Organizational. Behavior" Fourth Edition.
McGRAW-Hill International, United States of. America.

[12] Tandirerung Gloria.2015.The Influence of Competence, Accountability and Ethics of Auditors on audit quality (Case Study on BPKP Representative of Sul-sel Province). Desertation. Faculty of Economics and Business Hasanuddin University.

[13] Puspatriani Anissa. 2014. Influence of Independence and Due Professional Care on Audit Quality (Survey at Public Accounting Firm in Bandung). Bandung: Pasundan University

[14] Purnamasari, Anik. 2016. Influence of Independence, Competence, Experience, Due Professional Care and Accountability on Audit Quality (Empirical Study at the Office of the Inspectorate of Ex Karisdenan Surakarta). Publication Manuscript. Surakarta: University of Muhammadiyah 